\title{
Možnosti kvantitativních úloh ve výuce fyziky ${ }^{1}$
}

\author{
Possibilities of quantitative tasks in physics education \\ Marie Snětinová
}

\begin{abstract}
Abstrakt: ̌̌ešení kvantitativních úloh má v České republice ve výuce fyziky velkou tradici, což lze doložit relativně velkým počtem těchto úloh zařazených do učebnic a sbírek a jejich využíváním na školách. Řešení úloh se však u studentů často mění v „matematickou manipulaci“" se vzorci bez hlubšího pochopení základních fyzikálních konceptů. Tuto strategii je užitečné u studentů minimalizovat a naučit je vhodnějšímu přístupu. $V$ př́spěvku je prezentován projekt zaměřený na výukové metody zabývající se schopností řešit kvantitativní fyzikální úlohy a jejich konkrétní možný prrínos v podmínkách české vzdělávací soustavy. V návaznosti na výsledky rešerše na toto téma a na základě výzkumu bude vyvíjena metodika vhodná pro využití ve výuce na středních školách a v prvních ročnících vysokých škol. Cílem projektu je vytvoření metodických materiálů s popisem konkrétní metody a jejího použití ve výuce, včetně pracovních listů s vybranými úlohami. Použitelnost metodiky, ale zejména konkrétní přínos $\mathrm{k}$ rozvoji dovednosti studentů řešit fyzikální problémy a $\mathrm{k}$ praktickému pochopení fyzikálních principů, budou zkoumány metodou př́padových studií.
\end{abstract}

Klíčová slova: kvantitativní úlohy, výukové metody, fyzika

\begin{abstract}
Solving quantitative physics tasks has a long tradition in the Czech education system. Regrettably, many students solve the tasks without deeper understanding of the physical context and the solving often turns into simple "mathematical manipulation" with formulas. It is important to discourage this strategy and teach students more appropriate approach towards the issue. An example of such a strategy is described in (Van Heuvelen, 1991). This contribution presents a project focused on developing teaching methods that concern the skills how to solve quantitative physics tasks and analyzing their potential impact in the context of the Czech education system. Selected approaches will be developed into detailed methodological materials based on the results of international research survey on this subject and these will be adapted to the conditions of teaching in the first year of Czech universities and at the secondary schools. Applicability of the methodology, and especially concrete contribution to the development of skills of students to solve physics problems and practical understanding of the physical principles, will be explored using case studies.
\end{abstract}

Keywords: quantitative tasks, teaching methods, physics

\section{1 Úvod}

V současné době, a to zejména $\mathrm{v}$ zahraničí, je ve fyzikálním vzdělávání upřednostňováno spíše řešení kvalitativních úloh. Cílem těchto úloh je rozvíjet u studentů zejména pochopení základních fyzikálních konceptů. Pro studenty př́rodovědných a technických oborů je však důležitá i dovednost umět správně řešit kvantitativní úlohy.

\footnotetext{
${ }^{1}$ Práce na tomto textu byly podpořeny Grantovou agenturou Univerzity Karlovy (grant č. 374711).
} 


\section{Současný stav poznání}

Řešení kvantitativních úloh má v českém vzdělávacím systému velkou tradici. To lze dokladovat relativně velkým množstvím kvantitativních úloh zařazených do fyzikálních sbírek a učebnic (např. Lepil, 1995; Žák, 2011), stejně jako existencí cvičení doprovázejících základní kurzy fyziky na vysokých školách.

Kvantitativní úlohy jsou ve vyučování viděny jako relativně snadný způsob k procvičení získaných znalostí a k dosažení hlubšího pochopení fyzikálních konceptů. Je však nutno si připustit, že řešení úloh se často stává pouhou „matematickou manipulací“ se vzorci bez hlubšího pochopení fyzikálních zákonů. I studenti, kteří mohou být velmi úspěšní v řešení typových úloh, mohou mít zásadní nedostatky v pochopení základních konceptů. Tuto strategii řešení úloh je nutné u studentů minimalizovat a nahradit ji vhodnějšími postupy. Některé metody, které vznikly $\mathrm{v}$ zahraničí, jsou popsány např. v (Caliskan, Selcuk, \& Erol, 2010; Scarl, 2003; Van Ausdal, 1988; Van Heuvelen, 1991). Ukázka jedné metody je uvedena $\mathrm{v}$ tabulce 1 .

Tabulka 1

Ukázka metody řě̌ení úloh

1. Porozumění úloze

- Pozorné čtení zadání

- Přeformulování problému vlastními slovy

- Výčet daných veličin (včetně jejich jednotek)

- Výčet hledaných veličin (včetně jejich jednotek)

- Grafická vizualizace úlohy - zakreslení diagramů (nebo ujasnění souvislostí mezi daným diagramem a úlohou)

- Určení skalárních a vektorových vlastností daných a hledaných veličin

2. Kvalitativní analýza úlohy

- Určení hlavních fyzikálních konceptů úlohy

- Určení obecného př́stupu k úloze

- Vyjádření základních zákonů a pravidel týkajících se úlohy a stanovení, proč a jak je použít

3. Plán řešení úlohy

- Naplánování, jak získat hledané veličiny z veličin zadaných

- Zapsání vzorců souvisejících s daným problémem

- Zvážení, zda fyzikální vzorce sepsané pro daný problém jsou opodstatněné

- Zformulování konečného vzorce před prováděním algebraických operací

- Kontrola, zda se v konečném vzorci nevyskytují neznámé proměnné

4. Použití plánu řešení

- Použití zadaných veličin (včetně jejich jednotek) v konečném vzorci

- Pečlivé provedení všech matematických operací

5. Kontrola

- Kontrola, zda všechny hledané veličiny byly nalezeny

- Uvážení, zda nalezený výsledek je rozumný

- Kontrola fyzikálních jednotek výsledku

Pozn: Převzato z (Caliskan, Selcuk, \& Erol, 2010). 


\section{Cíle projektu}

Úkolem projektu je vytipovat metody a vhodné postupy výuky řešení fyzikálních úloh pro podmínky českého školství. Pro vybrané metody budou vytvořeny metodické materiály pro učitele, včetně pracovních listů s konkrétními úlohami.

Hlavním cílem studie je ověřit využitelnost metod i připravených metodických materiálů v praxi a zjistit jejich prínos k rozvoji dovednosti řešit kvantitativní fyzikální úlohy.

\section{Metoda}

Vybrané postupy a strategie řešení kvantitativních úloh budou testovány v podmínkách středních a vysokých škol. Výzkum proběhne na menším vzorku žáků a studentů metodami kvalitativního výzkumu, který umožňuje získat hlubší vhled do zkoumané problematiky. Přínos daných metod bude zjišt'ován metodou príípadových studií.

\section{Očekávané výsledky}

Analýza metod a postupů řešení fyzikálních úloh používaných v zahraničí umožní zefektivnit výuku řešení fyzikálních úloh na tuzemských středních školách a v základních kurzech fyziky v prvních semestrech studia fyziky na vysokých školách. Výsledky výzkumu zároveň přispějí $\mathrm{k}$ vylepšení tvorby úloh prezentovaných $\mathrm{v}$ elektronické sbírce řešených úloh $\mathrm{z}$ fyziky (viz http://www.fyzikalniulohy.cz/, projekt běžící na pracovišti KDF MFF UK již pátým rokem).

Na základě výsledků výzkumu budou stanoveny metodické postupy a vhodné způsoby výuky řešení fyzikálních úloh. Tyto postupy přispějí $\mathrm{k}$ hlubšímu porozumění fyzikálních konceptů a $\mathrm{k}$ rozvoji dovednosti studentů řešit fyzikální problémy.

\section{Literatura}

Caliskan, S., Selcuk, G. S., \& Erol, M. (2010). Instruction of problem solving strategies: Effects on physics achievement and self-efficacy beliefs. Journal of Baltic Science Education, 9(1), 20-34.

Lepil, O., et al. (1995). Fyzika: Sbirka úloh pro střední školy. Praha: Prometheus.

Scarl, D. (2003). How to solve problems: For success in freshman physics, engineering and beyond. New York: Dosoris Press.

Van Ausdal, R. G. (1988). Structured problem solving in kinematics. The Physics Teacher, 26(8), $518-522$.

Van Heuvelen, A. (1991). Learning to think like a physicist: A review or research-based instructional strategies. American Journal of Physics, 59(10), 891-897.

Žák, V. (2011). Fyzikální úlohy pro středni školy. Praha: Prometheus.

\section{Kontakt}

Mgr. Marie Snětinová

Univerzita Karlova v Praze

Matematicko-fyzikální fakulta, Katedra didaktiky fyziky,

V Holešovičkách 2, 18000 Praha 8

e-mail: marie.snetinova@mff.cuni.cz 


\section{Bibliografické údaje}

Snětinová, M. (2011). Možnosti kvantitativních úloh ve výuce fyziky. In T. Janík, P. Knecht, \& S. Šebestová (Eds.), Smišený design v pedagogickém výzkumu: Sborník př́spěvků z 19. výroční konference České asociace pedagogického výzkumu (s. 263-266). Brno: Masarykova univerzita.

Dostupné z: http://www.ped.muni.cz/capv2011/sbornikprispevku/snetinova.pdf doi: 10.5817/PdF.P210-CAPV-2012-66 